\title{
Variation in plasma prednisolone concentrations in renal transplant recipients given enteric-coated prednisolone
}

\author{
R G HENDERSON， T WHEATLEY，J ENGLISH，J CHAKRABORTY， V MARKS
}

British Medical fournal, 1979, 1, 1534-1536

\section{Summary and conclusions}

Renal transplant recipients receiving intermittent haemodialysis and kept under normal ward conditions showed appreciable differences in plasma prednisolone concentrations after therapeutic doses of enteric-coated prednisolone tablets. This gross day-to-day variation occurred irrespective of the dosage used. Breakfast given before prednisolone tended to reduce the rate of absorption of the drug, the effect being quantitatively most pronounced with large doses. Haemodialysis had no apparent effect on the elimination of prednisolone from plasma.

Such erratic blood concentrations of prednisolone as observed in these patients, possibly resulting from variable absorption, may be potentially hazardous. Hence use of enteric-coated tablets in renal transplant recipients should be viewed with caution.

\section{Introduction}

Corticosteroids and azathioprine constitute the mainstay of treatment in preventing rejection after renal transplantation. For the past 10 years patients in Cambridge have received corticosteroids as enteric-coated prednisolone in an effort to reduce the risk of peptic ulceration. ${ }^{1}$ Boluses of unabsorbed tablets, however, have commonly been found many hours after ingestion in the gut of patients who have required subsequent abdominal exploration.

To assess the day-to-day variation in intestinal absorption of prednisolone we monitored the plasma drug concentrations on two consecutive days in renal transplant recipients who received enteric-coated prednisolone tablets as part of routine treatment. In two other, separate studies we also examined the effects of haemodialysis on the disappearance of prednisolone from plasma and the way food influences prednisolone absorption.

\section{Patients and methods}

Patients from groups 1 and 2 were studied within three weeks after transplantation and while all but one still required intermittent haemodialysis. Patients from group 3 all had functioning grafts. No restrictions were placed on food and drink, and other drug treatment was continued unchanged. Table I gives details of the patients studied.

Study 1-Plasma prednisolone concentrations were measured in three women and five men (group 1) at various times after their respective oral doses $(100-200 \mathrm{mg})$ of the drug, which were given after breakfast. Measurements were made on two consecutive days, the

Department of Medicine, Addenbrooke's Hospital, Cambridge CB2 2QQ

R G HENDERSON, MB, MRCP, senior registrar (now consultant physician) $T$ WHEATLEY, MB, MRCP, registrar

Department of Biochemistry, University of Surrey, Guildford GU2 5XH

J ENGLISH, LIBIOL, research fellow in clinical biochemistry J CHAKRABORTY, PHD, senior lecturer in clinical biochemistry

V MARKS, DM, FRCPATH, professor of clinical biochemistry
TABLE I-Details of patients studied

\begin{tabular}{|c|c|c|c|c|}
\hline $\begin{array}{l}\text { Case } \\
\text { No }\end{array}$ & Sex & $\underset{\text { (years) }}{\text { Age }}$ & $\begin{array}{c}\text { Body weight } \\
(\mathrm{kg})\end{array}$ & $\begin{array}{c}\text { Creatinine } \\
\text { clearance }(\mathrm{ml} / \mathrm{min})\end{array}$ \\
\hline $\begin{array}{l}1 \\
2 \\
3 \\
4 \\
5 \\
6 \\
7 \\
8\end{array}$ & $\begin{array}{l}M \\
M \\
M \\
F \\
F \\
M \\
M \\
F\end{array}$ & $\begin{array}{c}\text { Group } 1 \\
38 \\
40 \\
28 \\
39 \\
28 \\
28 \\
33 \\
22\end{array}$ & $\begin{array}{l}73 \cdot 0 \\
76 \cdot 5 \\
64 \cdot 7 \\
62 \cdot 5 \\
70 \cdot 9 \\
66 \cdot 6 \\
61 \cdot 8 \\
62 \cdot 5\end{array}$ & $\begin{array}{r}0.4 \\
<1.0 \\
<1.0 \\
0.5 \\
0.8 \\
1.3 \\
2.0 \\
31.0\end{array}$ \\
\hline $\begin{array}{r}9 \\
10\end{array}$ & $\stackrel{\mathrm{M}}{\mathrm{F}}$ & $\begin{array}{c}\text { Group } 2 \\
50 \\
18\end{array}$ & $\begin{array}{l}66 \cdot 6 \\
53 \cdot 2\end{array}$ & $\begin{array}{l}<1 \cdot 0 \\
<1 \cdot 0\end{array}$ \\
\hline $\begin{array}{l}11 \\
12 \\
13 \\
14\end{array}$ & $\begin{array}{l}\mathrm{M} \\
\mathrm{F} \\
\mathrm{M} \\
\mathrm{M}\end{array}$ & $\begin{array}{c}\text { Group } 3 \\
52 \\
43 \\
35 \\
42\end{array}$ & $\begin{array}{l}73 \cdot 1 \\
55 \cdot 6 \\
65 \cdot 1 \\
70 \cdot 0\end{array}$ & $\begin{array}{l}66 \cdot 0 \\
57 \cdot 0 \\
36 \cdot 0 \\
18 \cdot 0\end{array}$ \\
\hline
\end{tabular}

tablets (Deltacortril R, CAP-coated $5 \mathrm{mg}$ tablets) being swallowed with water.

Study 2-The effect of haemodialysis on plasma prednisolone was studied on three occasions in one man and one woman (group 2). Prednisolone $80 \mathrm{mg}$ (Codelsol) was given intravenously on two consecutive days, on one of which haemodialysis was performed. The drug was administered at the start of dialysis. Timed venous specimens were taken for measurement of prednisolone.

Study 3-The effect of food on prednisolone absorption was studied in three men and one woman (group 3). Enteric-coated prednisolone was given as a single dose of 20 or $50 \mathrm{mg}$ on two consecutive mornings. The drug was administered 20 minutes after breakfast on the first day and after a six-hour fast on the second day. Timed venous specimens were collected for prednisolone assay.

Prednisolone measurement-Blood was centrifuged immediately and the plasma stored at $-20^{\circ} \mathrm{C}$ until assayed. The sample $(1 \mathrm{ml})$ was extracted with ethyl acetate $(3 \mathrm{ml} \times 2)$, the extracts being pooled and dried by evaporation at $40^{\circ} \mathrm{C}$ under a stream of nitrogen. The residue was reconstituted in $0.5 \mathrm{ml} 0.1 \mathrm{M}$ phosphate buffer, $\mathrm{pH} 7 \cdot 4$, and aliquots $(0.1 \mathrm{ml}$, either neat or appropriately diluted) analysed for prednisolone by radioimmunoassay. Table II gives the composition of the incubation mixture. Samples were incubated at $40^{\circ} \mathrm{C}$ for two hours, the rest of the procedure being as described. ${ }^{2}$

TABLE II-Composition of mixture used for radioimmunoassay. All volumes in $\mu$ l

\begin{tabular}{|c|c|c|c|c|c|c|}
\hline & & $\begin{array}{c}\text { Total } \\
\text { content }\end{array}$ & $\begin{array}{c}\text { Zero } \\
\text { standard }\end{array}$ & Standard & Sample & $\begin{array}{l}\text { Non- } \\
\text { specific } \\
\text { binding }\end{array}$ \\
\hline $\begin{array}{l}\text { Phosphate buffer }(0.1 \mathrm{~mol} / 1 \text {, } \\
\text { Standard }(0.10 \mathrm{ng})\end{array}$ & $1, \mathrm{pH} \mathrm{7 \cdot 4)}$ & 600 & 500 & $\begin{array}{l}400 \\
100\end{array}$ & 400 & 600 \\
\hline Sample aliquot $\quad \therefore$ & $\therefore \quad \cdots$ & & & & 100 & \\
\hline Label (10 nCi) & . $\quad \ldots$ & 100 & 100 & 100 & 100 & 100 \\
\hline Antibody ( $1 / 2250$ dilution) & $\ldots \quad \ldots$ & 100 & 100 & 100 & 100 & \\
\hline
\end{tabular}

\section{Results}

Tables III and IV show the cross-reactivity of the prednisolone antiserum with some other steroids and the accuracy and precision of the radioimmunoassay used. Two of the possible metabolites of prednisolone (prednisone and 20-dihydroprednisolone) showed appreciable cross-reactivities in the absence of prednisolone, but in the presence of prednisolone one of these (20-dihydroprednisolone) showed a reduction in cross-reactivity to under $10^{\circ}{ }_{0}$. Hence owing to the normally low concentrations of these steroids in blood, even when large amounts of prednisolone are present ${ }^{34}$ they were unlikely to interfere noticeably with the results. 
TABLE III-Cross-reactivity of various steroids with prednisolone antiserum in absence of prednisolone

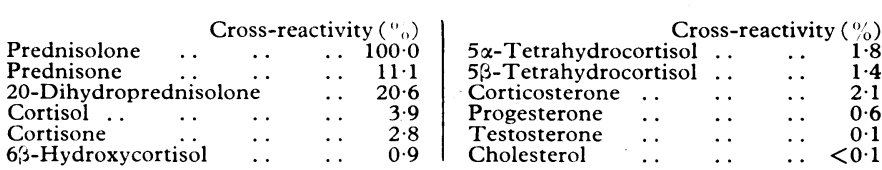

TABLE IV-Accuracy and precision of prednisolone radioimmunoassay

\begin{tabular}{|c|c|c|c|}
\hline \multirow[b]{2}{*}{$\begin{array}{l}\text { Amount of } \\
\text { prednisolone } \\
\text { added } \\
(\mathrm{ng} / \mathrm{ml})\end{array}$} & \multicolumn{2}{|c|}{ Within-batch } & \multirow[b]{2}{*}{$\begin{array}{l}\text { Between-batch: } \\
\text { coefficient of } \\
\text { variation }(\%) \\
(n=10)\end{array}$} \\
\hline & $\begin{array}{c}\text { Mean amount } \\
\text { measured } \\
(\mathrm{ng} / \mathrm{ml})\end{array}$ & $\begin{array}{l}\text { Coefficient of } \\
\text { variation }(\%) \\
(\mathrm{n}=10)\end{array}$ & \\
\hline $\begin{array}{r}1 \\
10\end{array}$ & $\begin{array}{l}1.05 \\
9.98\end{array}$ & $\begin{array}{l}5.9 \\
3.6\end{array}$ & $\begin{array}{l}7 \cdot 3 \\
5 \cdot 1\end{array}$ \\
\hline 100 & $99 \cdot 6$ & 4.9 & $7 \cdot 1$ \\
\hline
\end{tabular}

Replicate assays were carried out on pooled normal human plasma to which known amounts of prednisolone were added.

Patients in group 1 showed a gross variation in the rate of appearance of prednisolone in the blood and peak values achieved irrespective of the dosage used (table V). After the same dose given to different patients there was a difference in the time required to reach the peak plasma prednisolone concentration and, more strikingly, its magnitude between patients, as well as when the same subject was investigated on two separate occasions. In most instances the plasma concentration either peaked at four hours or continued to rise for another four hours.

TABLE $\mathrm{V}-$ Plasma prednisolone concentrations in group 1 after enteric-coated prednisolone tablets on two successive days

\begin{tabular}{|c|c|c|c|c|c|c|c|c|}
\hline \multirow{2}{*}{$\begin{array}{l}\text { Case } \\
\text { No }\end{array}$} & \multirow{2}{*}{$\begin{array}{l}\text { Dose } \\
(\mathrm{mg})\end{array}$} & \multirow{2}{*}{ Day } & \multicolumn{6}{|c|}{$\begin{array}{l}\text { Plasma prednisolone concentrations }(\mathrm{ng} / \mathrm{ml}) \text { at times } \\
\text { after dose }\end{array}$} \\
\hline & & & 0 & $0.5 \mathrm{~h}$ & $1 \mathrm{~h}$ & $2 \mathrm{~h}$ & $4 \mathrm{~h}$ & $8 \mathrm{~h}$ \\
\hline \multirow{2}{*}{1} & 200 & $\left\{1^{*}\right.$ & 67 & 83 & & 100 & 83 & 117 \\
\hline & 200 & & 67 & 900 & 1067 & 900 & 1017 & 1267 \\
\hline \multirow[t]{2}{*}{2} & 200 & & 0 & 90 & 100 & 3000 & 3350 & 2550 \\
\hline & & & $\begin{array}{r}420 \\
1020\end{array}$ & $\begin{array}{r}1300 \\
930\end{array}$ & $\begin{array}{r}1270 \\
880\end{array}$ & $\begin{array}{r}1270 \\
990\end{array}$ & 1060 & 2300 \\
\hline 2 & 175 & & 630 & 500 & 490 & 1470 & 4700 & 3350 \\
\hline \multirow{2}{*}{3} & 175 & & 955 & & 898 & 852 & 943 & 1057 \\
\hline & & & 375 & 295 & 227 & 841 & 1875 & 716 \\
\hline \multirow[t]{2}{*}{4} & 175 & & 450 & 388 & 400 & 500 & 2500 & 2475 \\
\hline & & & $\begin{array}{l}400 \\
933\end{array}$ & $\begin{array}{r}325 \\
1067\end{array}$ & $\begin{array}{r}250 \\
1333\end{array}$ & $\begin{array}{r}188 \\
1367\end{array}$ & $\begin{array}{r}163 \\
1400\end{array}$ & $\begin{array}{r}423 \\
1017\end{array}$ \\
\hline 5 & 150 & & 600 & 850 & 1150 & 2933 & 2800 & 1367 \\
\hline \multirow[t]{2}{*}{4} & 125 & & 25 & 38 & 25 & 40 & 25 & 75 \\
\hline & & & 267 & $\begin{array}{l}450 \\
183\end{array}$ & $\begin{array}{l}300 \\
117\end{array}$ & $\begin{array}{l}250 \\
183\end{array}$ & $\begin{array}{l}613 \\
900\end{array}$ & 688 \\
\hline 6 & 125 & 1 & 133 & 67 & 550 & 717 & 1533 & 833 \\
\hline \multirow{2}{*}{7} & 100 & $1^{*}$ & 160 & 170 & 240 & 200 & 350 & 1350 \\
\hline & & & 70 & 1070 & 570 & 660 & 1300 & 670 \\
\hline \multirow[t]{2}{*}{8} & 100 & $\left\{\begin{array}{l}1^{*} \\
2\end{array}\right.$ & 396 & 281 & 271 & & 708 & 979 \\
\hline & & & & & 73 & 63 & 63 & 406 \\
\hline
\end{tabular}

* Haemodialysis carried out.

Since in most cases the concentrations had not returned to zero by 24 hours, the values recorded over the eight hours after ingestion probably included the remains of previous doses. The overall peak concentrations ranged from 117 to 3350,423 to 4700,688 to 1533 , and 406 to $1350 \mathrm{ng} / \mathrm{ml}$ after $200,175,125$, and $100 \mathrm{mg}$ doses respectively. In case 1 after a $200 \mathrm{mg}$ dose on day 1 and in case 4 after $175 \mathrm{mg}$ on day 2 and $125 \mathrm{mg}$ on day 1 , the plasma prednisolone concentrations rose only marginally above basal values.

When the drug was given after a six-hour fast (group 3) peak plasma prednisolone concentrations were achieved in almost all cases within four hours (table VI). Breakfast taken before dosing, however, resulted in a delay of 7-10 hours before peak values were reached. Fasting before taking the prednisolone produced up to eightfold higher peak concentrations after 175 and $150 \mathrm{mg}$ doses (case 14), but this effect was not observed after 20 and $50 \mathrm{mg}$ doses (cases 11-13).

The figure shows the plasma prednisolone concentrations after the $80 \mathrm{mg}$ dose given intravenously (group 2). Plasma half lives ranged from 3.3 to 4.2 hours and showed no change that could be clearly attributed to haemodialysis.
TABLE VI-Effect of food on plasma prednisolone concentrations in group 3

\begin{tabular}{|c|c|c|c|c|c|c|c|c|}
\hline \multirow{2}{*}{$\begin{array}{l}\text { Case } \\
\text { No }\end{array}$} & \multirow{2}{*}{$\begin{array}{l}\text { Dose } \\
\text { (mg) }\end{array}$} & \multirow{2}{*}{$\begin{array}{c}\text { Break- } \\
\text { fast }\end{array}$} & \multicolumn{6}{|c|}{ Plasma prednisolone concentrations ${ }^{3} \mathrm{ng} / \mathrm{ml}$ ) at times } \\
\hline & & & 0 & $2 \mathrm{~h}$ & $4 \mathrm{~h}$ & $7 \mathrm{~h}$ & $10 \mathrm{~h}$ & $14 \mathrm{~h}$ \\
\hline \multirow{5}{*}{11} & \multirow{5}{*}{50} & Yes & 16 & 66 & 93 & 104 & 122 & 128 \\
\hline & & Yes & 17 & 47 & 128 & 106 & 108 & 109 \\
\hline & & No & 34 & 53 & 96 & 356 & 178 & 48 \\
\hline & & No & 144 & 200 & 378 & 200 & 189 & 106 \\
\hline & & Yes & 56 & 77 & 176 & 163 & 103 & 105 \\
\hline \multirow{4}{*}{12} & \multirow{4}{*}{50} & Yes & 58 & 88 & 95 & 178 & 178 & 120 \\
\hline & & No & 74 & 183 & 173 & 115 & 103 & 88 \\
\hline & & No & 65 & 175 & 175 & 114 & 101 & 92 \\
\hline & & Yes & 34 & 27 & 30 & 36 & 88 & 48 \\
\hline \multirow{3}{*}{13} & \multirow{3}{*}{20} & Yes & 25 & 18 & 36 & 118 & 98 & 50 \\
\hline & & No & 18 & 59 & 77 & 136 & 91 & 41 \\
\hline & & ( No & 20 & 18 & 173 & 127 & 91 & 48 \\
\hline \multirow{4}{*}{14} & \multirow{2}{*}{175} & Y Yes & 29 & 165 & 157 & 177 & 169 & \\
\hline & & No & 82 & 936 & 1068 & 499 & 388 & \\
\hline & \multirow[t]{2}{*}{150} & Yes & 60 & 41 & 43 & 47 & 49 & \\
\hline & & No & 58 & 870 & 821 & 668 & 412 & \\
\hline
\end{tabular}

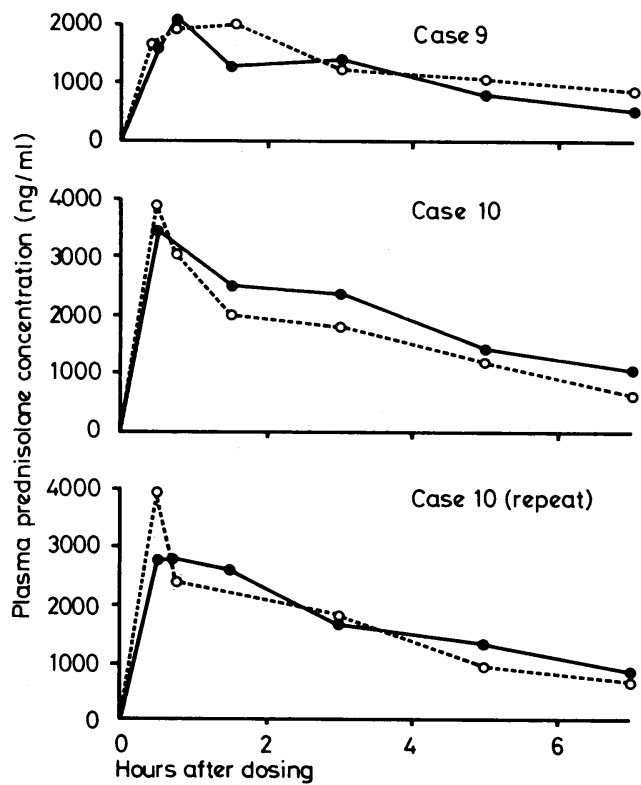

Plasma prednisolone concentrations in cases 9 and 10 (group 2) after intravenous injection of $80 \mathrm{mg}$ prednisolone on two consecutive days. -First day. - - Second day. On second day patient received haemodialysis and drug was given at start of treatment.

\section{Discussion}

Gross day-to-day variation in plasma prednisolone concentrations were observed in patients studied within three weeks after transplantation. The explanation is probably multifactorial: it may be related to the bioavailability of the drug formulation, the influence of haemodialysis on drug disposition in the body, the effect of food on intestinal absorption, and the patient's gastrointestinal activity.

Sherlock and Lerreri, ${ }^{5}$ who examined the effect of haemodialysis on 6-methylprednisolone, reported significant dialysance of the drug and suggested that the dosage might require adjustment. We found no evidence to support this, since haemodialysis immediately after an intravenous injection of prednisolone made no noticeable difference to the clearance of the drug.

Enteric coating influences the pharmacokinetics of prednisolone. ${ }^{6}{ }^{7}$ It delays the appearance of prednisolone in the blood but does not alter its bioavailability as compared with the uncoated drug when given in $10-20 \mathrm{mg}$ doses to healthy volunteers and patients with lung disease. In a study of patients who had undergone renal transplantation one to three years before, the peak plasma prednisolone concentration attained after $30 \mathrm{mg}$ of enteric-coated tablets was much lower than after the same dose of the plain preparation. ${ }^{8}$ No other investigators have examined the variation in plasma prednisolone concentrations with re- 
peated administration of the drug. Although absorption of the preparation we used is reportedly better ${ }^{9}$ than other preparations studied, erratic absorption of the large number of $5 \mathrm{mg}$ tablets ingested by our patients-who may have had impaired gastrointestinal function because of recent abdominal surgery-seems most likely to explain the observed wide scatter in plasma prednisolone concentrations. We cannot say whether altered metabolism of the drug in these patients was contributory. Since the patients ate and drank normally during the study we could not assess the extent to which food in the gut influenced drug absorption in group 1. In group 3, however, it appeared that whereas at lower doses the main effect of breakfasting before drug ingestion was to delay prednisolone absorption (which has also been noted with uncoated tablets $\left.{ }^{11}\right)$, at higher doses it also greatly reduced the plasma drug concentrations observed over the period studied.

Such very low plasma prednisolone concentrations as observed in some of our patients might be potentially hazardous, possibly favouring graft rejection. Although administration of the drug to patients who are fasting may improve intestinal absorption, this seems unlikely to be a complete answer. Possibly the enteric coating is responsible for erratic absorption. Since any advantage that has been claimed for the coating in preventing peptic ulceration is questionable, ${ }^{11}$ the continued use of this preparation needs reappraisal. Alternatively, it may be that absorption of the drug given as a large number of small tablets is less uniform than if the same dose was administered as one or more larger tablets. Clearly, such implications warrant further study.

We thank Professor R Y Calne and Dr D B Evans for allowing us to study patients under their care. Financial support from Pharmax Limited and the Arthritis and Rheumatism Council is gratefully acknowledged.

\section{References}

1 West, H F, British Medical fournal, 1959, 2, 680.

2 Chakraborty, J, et al, British fournal of Clinical Pharmacology, 1976, 3, 903

${ }^{3}$ Meikle, A W, Weed, J A, and Tyler, F H, fournal of Clinical Endocrinology and Metabolism, 1975, 41, 717 .

4 Sandberg, A A, and Slaunwhite, W R, Fournal of Clinical Endocrinology and Metabolism, 1957, 17, 1040.

5 Sherlock, J E, and Lerreri, J M, Nephron, 1977, 18, 208.

${ }^{6}$ Morrison, P J, Bradbrook, I D, and Rogers, H J, British fournal of Clinical Pharmacology, 1977, 4, 597.

Wilson, C G, May, C S, and Paterson, J W, British fournal of Clinical Pharmacology, 1977, 4, 351

* Hulme, B, James, V H T, and Rault, R, British fournal of Clinical Pharmacology, 1975, 2, 317.

${ }^{9}$ Lee, D A H, et al, British fournal of Clinical Pharmacology. In press.

10 Uribe, M, et al, Gastroenterology, 1976, 71, 362.

\title{
Raised blood pressure and plasma noradrenaline concentrations in teenagers and young adults selected from an open population
}

\author{
A HOFMAN, F BOOMSMA, M A D H SCHALEKAMP, H A VALKENBURG
}

British Medical fournal, 1979, 1, 1536-1538

\section{Summary and conclusions}

Plasma noradrenaline (PNA) concentrations were measured in 38 subjects aged $13-23$, who were followed up for two to four years after an initial blood-pressure (BP) reading of $140 / 90 \mathrm{~mm} \mathrm{Hg}$ or over was obtained, and in 39 age-matched controls from the same open population. Subjects who were hypertensive when the PNA concentration was measured had a significantly higher concentration (351 SE $26 \mathrm{pg} / \mathrm{ml})$ compared with their controls $(248+29 \mathrm{pg} / \mathrm{ml})$. Furthermore, in those subjects in whom the mean arterial pressure decreased by under $5 \%$ during the follow-up period the mean concentration was $363 \pm 27 \mathrm{pg} / \mathrm{ml}$, compared with $271 \pm 29 \mathrm{pg} / \mathrm{ml}$ in their controls. PNA concentrations and systolic BP were positively correlated. A positive association between PNA concentrations and age was observed in the controls but not the subjects with hypertension, owing to the higher concentrations in younger hypertensive subjects.

Medical Faculty, Erasmus University, Rotterdam, The Netherlands A HOFMAN, MD, resident, department of epidemiology

F BOOMSMA, PHD, research chemist, department of internal medicine I

$M$ A D H SCHALEKAMP, MD, senior lecturer, department of internal medicine I

H A VALKENBURG, MD, professor of epidemiology
These findings support the hypothesis that excessive sympathetic activity is related to early essential hypertension.

\section{Introduction}

Evidence is increasing that essential hypertension has its roots in childhood. Persistently raised blood pressure (BP) is not uncommon in children, ${ }^{1-3}$ who tend to keep their relative positions in the distribution of BP over time, ${ }^{45}$ possibly from the first months of life. ${ }^{6}$ The hypothesis has been proposed that overactivity of the sympathetic nervous system plays an important part in the pathogenesis of essential hypertension in its early phase, and that other factors-for example, kidney changes-are more important later. ${ }^{7}$ As a reflection of this, plasma catecholamine concentrations would be expected to be increased in young people with raised BP. Until now only studies of plasma catecholamine concentrations in adults ${ }^{8-1 s}$ and a few adolescents ${ }^{14}$ have been reported, and the data have been equivocal. We have measured the plasma noradrenaline (PNA) concentration in young people with potential hypertension and matched controls selected from the same population.

\section{Subjects and methods}

Blood pressure was measured as part of a tracking study of indicators of cardiovascular risk (EPOZ study) in 3924 children and teenagers initially aged $5-19$, representing $82 \%$ of the population in that age group living in two districts in a Dutch town. Subjects with an 